\title{
Pergeseran Orientasi dan Ekspresi Elit Pesantren di Kota Tasikmalaya
}

\author{
Akhmad Satori, ${ }^{1}$ Taufik Nurohman $^{2}$ \\ Jurusan Ilmu Politik FISIP Universitas Siliwangi, Tasikmalaya \\ (e-mail: akhmadsatori@unsil.ac.id; 2taufiknurohman@unsil.ac.id)
}

\begin{abstract}
This study focuses on the changing of orientation and expression among the elites of pesantren in Tasikmalaya in the effort to form a community life that is in accordance with the culture and values of Islamic teachings. To answer the questions, a descriptive-qualitative research method with a phenomenological approach is used in this study. The results of the study show that there are differences in views related to religious relations with the state, especially those which related to the intersection of Islamic Law with the legal system that applies among pesantren in Tasikmalaya. The first view states that to find solutions to various problems of society and in forming an Islamic society requires the involvement of the State; The second view states that to form an Islamic society does not need to involve the state. This view is more supportive of the implementation of religious ethics or morals with a cultural approach. The third view is the view which is a compromise between the two groups in the making of regulations.
\end{abstract}

Studi ini berfokus pada perubahan orientasi dan ekspresi elit-elit pesantren di Kota Tasikmalaya dalam upayanya membentuk suatu kehidupan masyarakat yang sesuai dengan kultur dan nilainilai ajaran Islam. Untuk menjawab penelitian ini, maka metode penelitian yang digunakan dalam penelitian ini adalah metode penelitian deskriptif-kualitatif dengan pendekatan fenomenologi. Hasil penelitian menunjukan adanya perbedaan pandangan berkait dengan relasi agama dengan Negara, khususnya yang berkaitan dengan persinggungan syariat Islam dengan sistem hukum yang berlaku di kalangan pesantren di Tasikmalaya. Pandangan pertama menyatakan bahwa untuk mencari solusi berbagai persoalan masyarakat dan dalam membentuk masyarakat yang Islami memerlukan keterlibatan Negara; Pandangan kedua menyatakan bahwa untuk membentuk masyarakat Islami tidak perlu melibatkan negara. Pandangan ini lebih mendukung pelaksanaan etika atau moral agama dengan pendekatan kultural. Pandangan ketiga,adalah pandangan yang merupakan kompromi antara kedua kelompok tersebut dalam pembuatan perda.

Keywords: syariat Islam; orientasi; ekspresi; elit pesantren 


\section{Pendahuluan}

Dalam upaya untuk membentuk kehidupan masyarakat yang sesuai dengan tatanan kultur dan nilai-nilai ajaran Islam para elit pesantren di Kota Tasikmalaya melakukan orientasi dan menunjukkan ekspresi yang spesifik. Para elit pesantren tidak lagi menempuh cara konvensional maupun cara kultural untuk membentuk kehidupan masyarakat, namun harus melibatkan negara dengan membuat kebijakan yang berisi tentang pengaturan kehidupan masyarakat agar sesuai dengan kultur dan ajaran Islam (Effendy 2009). Selain sebatas bekerja pada politik extra-parliamentary dengan memengaruhi pembuatan kebijakan agar sesuai dengan nilai ajaran Islam, para elit pesantren pun tidak sedikit yang secara langsung terlibat dalam politik parliamentary (Huntington 2000).

Terkait dengan hal tersebut, orientasi dan ekspresi keislaman masyarakat terkait dengan relasi Islam dan negara dalam setiap perubahan rezim di sebuah negara sangat menarik untuk diteliti. Hal ini karena setiap orientasi dan ekspresi keagamaan masyarakat dalam sejarah Indonesia selalu berkaitan dengan bagaimana tipe sebuah rezim. Seperti ketika Indonesia berada di bawah Orde Baru yang represif terhadap ekspresi-ekspresi masyarakat yang membahayakan eksistensi rezim (Muntoha 2010). Namun demikiam, orientasi dan ekspresi keagamaan muncul dalam bentuk yang beragam ketika Indonesia memasuki era reformasi. Era reformasi di Indonesia memiliki penanda bahwa setiap masyarakat mendapatkan kembali kebebasan berorientasi dan berekspresinya, seperti bermunculan ide-ide penegakan syariat Islam ataupun ide formalisasi hukum Islam kedalam sistem hukum nasional (Bubalo dan Meson 2008; Ilahi 2014).

Memahami relasi Islam dan negara dalam konteks Indonesia tidak akan bisa lepas dari kajian yang dilakukan para ilmuwan dan Indonesianis yang banyak membahas mengenai hal ini, sebut saja Martin van Bruinessen, Karl D. Jackson, Uhlin, William Liddle, Harold Crouch, Mitsuo Nakamura, dan Robert Hefner, begitu juga dengan para pemikir Islam Indonesia seperti Kuntowijoyo, Fachri Ali, Bachtiar Effendi, Sukron Kamil, Askar Salim dan banyak lagi. Kajian formalisasi Islam dalam arti penerapan syariah di semua lapangan kehidupan, juga muncul dalam hubungan Islam dan Negara. Seperti kajian fundamentalisme Islam dalam gerakan DI/TII dalam dinamika politik lokal (Jackson 1990). Gagasan Islam Substansial atau kultural inklusif yang berbeda dengan Islam skriptual (Liddle 1997), Islam tradisionalis dan nasionalis (Effendy 2009), hubungan Islam dan demokrasi Indonesia (Hefner 1995; Uhlin 1995). Perkembangan proses Islamisasi yang dijelaskan oleh Arskal Salim bagaimana sejarah dan dinamika perkembangan gerakan syariat Islam yang ia sebut sebagai "Islamization", proses Islamisasi tersebut telah melalui tiga fase pada periode modern di Indonesia (Salim 2008).

Berbicara bagaimana orientasi dan ekspresi keislaman masyarakat dalam sebuah negara akan terkait erat dengan berbagai macam pandangan mengenai relasi Islam dan negara. Terdapat tiga paradigma yang mengkerangkai perdebatan relasi Islam dan negara yaitu, Pertama, paradigma integralistik. Agama dan 
negara menyatu. Wilayah negara meliputi politik atau negara. Negara merupakan lembaga politik dan keagamaan sekaligus. Kedua, paradigma simbiotik. Agama dan negara menurut paradigma ini, berhubungan secara simbiotik, yakni suatu hubungan yang bersifat timbal balik dan saling memerlukan. Ketiga, paradigma sekularistik. Paradigma ini mengajukan pemisahan agama atas negara dan negara atas agama (Nasir 2007). Dengan demikian menurut paradigma ini, hukum Islam tidak dapat begitu saja diterapkan dan diberlakukan dalam suatu wilayah politik tertentu.

Berbagai tuntutan yang diekspresikan oleh beberapa kelompok Islam yang menginginkan penegakan syariat Islam terlihat tidak hanya terjadi pada level nasional, reformasi dan otonomi daerah membuka peluang bagi mereka untuk melakukan tuntutan tersebut pada level daerah. Kota Tasikmalaya adalah salah satu daerah di Jawa Barat yang dikenal sebagai daerah yang telah membuat Perda Syariat Islam yakni Peraturan Daerah Kota Tasikmalaya No. 12 Tahun 2009 tentang Pembangunan Tata Nilai Kehidupan Kemasyarakatan yang Berlandaskan pada Ajaran Agama Islam dan Norma-norma Sosial Masyarakat Kota Tasikmalaya dan Peraturan Daerah No. 7 Tahun 2014 yang substansinya tidak jauh berbeda. Dalam hal masuknya syariat Islam menjadi isu kebijakan di Kota Tasikmalaya dapat ditelusuri sebagai hasil dari sebuah gerakan Islamisasi yang melibatkan negara dalam upaya Islamisasinya sebagai bagian dari orientasi dan ekspresi politik Islam, dimana hal ini dapat dilihat dari isi perda tersebut mempunyai semangat untuk menanamkan nilai- nilai ajaran Islam kepada masyarakat Kota Tasikmalaya.

Apa yang terjadi di Kota Tasikmalaya ini menarik untuk diteliti, ketika upaya Islamisasi masyarakat yang dilakukan oleh elit-elit pesantren yang merupakan bagian dari manifestasi orientasi dan ekspresi politiknya yang biasanya selalu didasari oleh pemikiran Islam subtanstif tanpa melibatkan negara mengalami pergeseran ke arah orientasi dan ekspresi seperti yang biasa terlihat dari mereka yang mendasarkan diri pada pemikiran Islam simbolis dimana didalam gerakannya bersinggungan dengan negara atau bahkan melibatkan Negara (Nasir 2007).

Pemberlakuan Perda Syariat Islam di daerah Tasikmalaya -sebagai salah satu bentuk ekspresi keagamaan- dapat dilihat pula pada kajian Suismanto (2007). Wacana untuk menerapkan syariat Islam menemukan kembali momentumnya dengan jatuhnya pemerintahan Orde Baru. Hal ini semakin menguat setelah keluar Undang-Undang No. 22 Tahun 1999 tentang Otonomi Daerah, yang direvisi menjadi Undang-Undang No. 32 Tahun 2004 tentang Pemerintahan Daerah. Beberapa Perda dan Himbauan Bupati lahir untuk mengatur berbagai perilaku keagamaan masyarakat. Namun demikian pemberlakuan Perda syariat Islam itu tidak serta merta memberikan hasil, ada beberapa persoalan yang menghinggapi peraturan tersebut, baik pada ranah konseptual, sosial, budaya dan politik (Suismanto 2007).

Penelitian ini memfokuskan diri pada perubahan orientasi dan ekspresi elit pesantren di Kota Tasikmalaya. Dinamika politik berupa 
desentralisasi dan menguatkan fenomena spiritualisasi dalam kehidupan sosial telah menguatkan semangat lokal untuk mengekspresikan diri dalam bentuk ekspresi struktural sosial. Oleh karena itu, secara rinci pertanyaan yang akan dijawab dalam penelitian ini adalah bagaimana peta perubahan ekspresi dan orientasi para elite pesantren di Tasikmalaya dalam menghadapi perubahan sosial dan struktural, dan mengapa peta itu terjadi.

Dengan problematika tersebut, maka metode yang digunakan dalam penelitian ini adalah metode deskripsi-kualitatif dengan pendekatan fenomenologi. Pendekatan fenomenologi dipilih dalam penelitian ini karena pendekatan ini melibatkan pengujian yang teliti dan seksama pada kesadaran pengalaman manusia. Konsep utama dalam fenomenologi adalah makna (Denzin dan S. Lincoln 2009). Makna merupakan isi penting yang muncul dari pengalaman kesadaran manusia. Untuk mengidentifikasi kualitas yang essensial dari pengalaman kesadaran dilakukan dengan mendalam dan teliti (Smith, Flowers, dan Larkin 2009). Dengan kajian fenomenologi yang seperti itu diharapkan peta pandangan para elite pesantren terhadap konstalasi politik di Tasikmalaya dapat digali hingga tahapan makna. Demikian pula penyebab dari munculnya ekspresi dan orientasi para elite itu pun dapat digali secara mendalam.

\section{Perbedaan Cara Pandang dalam Menghadapi Perubahan Sosial Masyarakat Kota Tasikmalaya}

Kota Tasikmalaya adalah salah satu daerah otonom di wilayah Provinsi Jawa Barat.
Sebagai salah satu daerah pusat islamisasi di kawasan Priangan Timur ${ }^{1}$, nuansa Islam di Kota Tasikmalaya sangat terlihat dalam kehidupan beragama dan bermasyarakat, selain juga terlihat dalam kehidupan bernegara dan kehidupan politik. Maksudnya adalah bahwa nuansa Islam tidak hanya tampak menonjol dalam konteks kehidupan masyarakat saja melainkan Islam juga mewarnai kehidupan politik di Kota Tasikmalaya. Salah satu contoh menonjolnya warna Islam dalam kehidupan politik di Kota Tasikmalaya adalah dominannya kemenangan partai Islam dibandingkan partai-partai lain yang tidak berlabel Islam. Partai Persatuan Pembangunan misalnya, yang merupakan partai dengan ideologi Islam selalu menjadi pemenang pada setiap pemilu yang diselenggarakan pasca Orde Baru di Tasikmalaya.

Selain nuansa Islam terlihat dalam politik formal, nuansa Islam, nilai maupun simbolsimbol Islam juga sangat terlihat pada politik ekstraparlementer khususnya ketika melihat gerakan Islam di Kota Tasikmalaya. Walaupun ketika membahas gerakan Islam itu tidak akan lepas dari kecenderungan gerakan Islam dalam skala nasional, dimana perkembangan gerakan Islam sangat kaya akan varian hingga kemudian memunculkan nama atau istilah yang

\footnotetext{
${ }^{1}$ Tasikmalaya dikenal dengan kota Santri karena memiliki jumlah pesantren yang banyak, baik di Kota maupun di Kabupaten Tasikmalaya. Julukan sebagai kota santri ini disematkan kepada Kota Tasikmalaya karena masyarakatnya yang menunjukan sebuah kehidupan yang religius Tercatat sekitar 900 an pesantren yang ada di wilayah ini, tidak heran jika Tasikmalaya di sebut sebagai pusat islamisasi di wilayah Priangan Timur.
} 
beragam seperti Islam tradisionalis, Islam modernis, Islam skriptualis, Islam subtantif, Islam literalis, Islam militan, Islam abangan, Islam esktrimis dan lain sebagainya. Tetapi dalam konteks Kota Tasikmalaya khususnya dalam penelitian ini terlihat ada gerakan Islam yang menghendaki penegakan syariat Islam melalui peraturan daerah pada satu kutub dan mereka yang tidak menghendaki hal itu terjadi melainkan lebih menekankan gerakan mereka pada gerakan-gerakan kultural.

Untuk melihat bagaimana pergeseran orientasi dan ekspresi para elit pesantren di Kota Tasikmalaya penelitian mencoba untuk melihat bagaimana para elit itu memandang suatu persoalan yang terjadi di masyarakat. Konstalasi sosial dan politik yang dialami oleh masyarakat secara global tidak dapat dielakkan oleh masyarakat Tasikmalaya. Secara sosial budaya masyarakat Kota Tasikmalaya sedang mengalami perubahan sangat krusial yang saat ini. Masyarakat Kota Tasikmalaya yang semula sangat kental dengan nilai-nilai religiusitasnya semakin bergerak kepada masyarakat yang tidak lagi memegang teguh nilai-nilai religiusitas tersebut.

Walaupun nuansa keislaman sangat kental dalam kehidupan masyarakat, namun di tengah gempuran modernisasi, masyarakat Kota Tasikmalaya yang dikenal sebagai "kota santri" pada akhirnya menemui tantangannya tersendiri. Bersamaan dengan datangnya perkembangan dan modernisasi di Kota Tasikmalaya, timbul dampak negatif yang pada akhirnya bermuara pada rusaknya moral dan perilaku warga masyarakat. Kota Tasikmalaya sedang menunjukkan perubahan sosial yang negatif seperti, kebiasaan mabuk-mabukan, prostitusi dan penyakit sosial lainnya. ${ }^{2}$

Berbagai kemerosotan moral akibat dari serangan ekternal tersebut menimbulkan resistensi dari sebagian masyarakat Muslim khususnya para ajengan ${ }^{3}$ atau kai dan elit-elit pesantren di Kota Tasikmalaya. Mereka berpendapat bahwa kuatnya serangan eksternal ini tidak bisa dilawan hanya dengan pendidikan agama maupun dengan upaya-upaya kultural, sehingga kemudian harus dicari sebuah alternatif yang dapat menjadi solusi untuk membendung serangan tersebut. Disisi lain, sebagian dari mereka menganggap bahwa elit-elit yang menduduki kursi-kursi di pemerintahan tidak mampu membendung serangan ini. Maraknya korupsi, menjamurnya kejahatan politik, lemahnya penegakan hukum, rendahnya kesejahteraan masyarakat yang dianggap akibat dari sejumlah besar penyalahgunaan kekuasaan oleh para elit justru semakin terlihat.

2Beberapa fakta menunjukan bahwa modernisasi di Tasikmalaya menyebabkan perubahan gaya hidup sosial masyarakatnya menjadi hedonis dan berperilaku negatif yang terlihat juga dari tingginya kasus narkoba, HIV-AIDS, pelacuran, perjudian dan juga maraknya praktek-praktek riba. Selain daripada itu, derasnya arus teknologi dan komunikasi membawa efek terhadap terkikisnya moral dan perilaku masyarakat. Wawancara dengan Edi Kusmayadi.

3Sebagaimana yang dijelaskan Clifford Geertz (1983) yang mengkaji tentang Kyai Jawa, Ajengan memainkan peranan penting dalam kehidupan masyarakat. Mereka berperan sebagai cultural broker dan juga pengayom bagi masyarakat di sekitarnya. Selain itu juga, para Kyai juga sering ikut terlibat dalam pergumulan sosial politik dan sosial budaya sebagai agen of change. 


\section{Pergeseran Orientasi dan Ekspresi Elit Pesantren di Kota Tasikmalaya}

Seperti yang telah dijelaskan sebelumnya bahwa salah satu pandangan mengenai relasi Islam dan negara menganggap bahwa negara tidak perlu secara resmi menjadi negara agama (negara Islam) tetapi lebih kepada bagaimana etika agama Islam memberikan sumbangan peran pada kehidupan negara. Etika agama tersebut hanya dijadikan sebagai landasan moral dalam pengelolaan negara. Pandangan ini menolak formalisasi agama, hal ini karena formalisasi agama dalam sebuah negara hanya akan mengerdilkan agama Islam itu sendiri, sehingga Islam semakin sempit, hanya sebatas yang dipahami oleh penafsir (Qodir 2012: 21). Pandangan seperti ini kemudian dikenal sebagai pandangan Islam subtansialis, dimana mereka yang sepakat dengan pandangan ini lebih meletakan dan mengartikulasikan Islam secara subtansial.

Dalam mengekspresikan pandangannya, para kaum subtasialis di Kota Tasikmalaya melakukan perjuangan kultural dalam menghadapi tantangan perubahan zaman. Upaya ini juga sesuai dengan sebagaimana yang telah dilakukan para ulama-ulama terdahulu di wilayah Priangan Timur termasuk di Tasikmalaya dimana mereka terlebih dahulu menjadikan Islam sebagai pijakan kultural masyarakat melalui akulturasi dengan budaya Sunda sehingga kemudian dapat diterima dengan lebih mudah oleh masyarakat tersebut. Dengan menjadikan Islam sebagai bagian dari kultur masyarakat, maka dapat dengan sendirinya masyarakat akan menjalankan kehidupan yang sesuai dengan nilai-nilai kultural tersebut.

Pola gerakan keagamaan yang dilakukan oleh pesantren selama ini menggambarkan pada pola-pola perjuangan Islam yang lebih dekat dengan pola perjuangan Islam subtantif. Pola-pola perjuangan Islam yang lebih mengedepankan pendekatan kultural. Untuk membentuk masyarakat yang islami ditempuh melalui sistem pendidikan dan penyadaran langsung terhadap masyarakat daripada caracara institusional atau menginstitusionalisasikan nilai-nilai Islam ke dalam hukum formal maupun kebijakan negara. Namun, apa yang terjadi di Kota Tasikmalaya khususnya pada pasca tumbangnya Orde Baru memperlihatkan gambaran yang berbeda. Beberapa dari kalangan elit pesantren justru menampakan suatu gerakan yang terlihat tidak lagi seperti gerakan-gerakan Islam subtantif tetapi lebih mengarah kepada gerakan simbolik. Hal ini terlihat jelas ketika terbentuknya peraturan daerah yang bertujuan untuk membentuk masyarakat Islami.

Secara garis besar, kelompok Islam simbolik ini dalam cita-citanya mewujudkan masyarakat yang Islami melalui pelibatan negara. Dimana, menurut pandangan mereka Islam dan negara itu tidak bisa dipisahkan. Bahkan tidak sedikit dari mereka yang memposisikan Islam tidak hanya sebagai sebuah sistem kepercayaan tetapi juga sebagai sebuah ideologi. Selain itu mereka memperjuangkan penegakan syariat Islam, dimana syariat Islam tersebut dijadikan sebagai pedoman dalam menjalani kehidupan masyarakat. Upaya pe- 
negakan syariat Islam ini merupakan bagian penting dalam perjuangan Islam, dimana dalam hal ini mereka menegaskan bahwa ajaran Islam merupakan satu-satunya sumber identitas, makna, stabilitas, legitimasi, kemajuan, kekuatan dan harapan yang dinyatakan melalui slogan "Islam adalah jalan keluar". Upaya dalam menemukan "jalan keluar" tidak lagi melalui ideologi-ideologi barat tetapi melalui nilai-nilai yang ada dalam ajaran Islam. Mereka berkomitmen terhadap Islam sebagai satu-satunya petunjuk hidup di dunia modern.

Kemunculan kelompok Islam yang menginginkan formalisasi syariat Islam melalui kebijakan negara merupakan ekspresi dan respon terhadap hegemoni nilai-nilai barat dalam kehidupan masyarakat modern. Kondisi kehidupan masyarakat modern yang didominasi nilai-nilai barat dan nilai-nilai sekuler dianggap sebagai sebuah krisis yang harus segera ditangani. Islam menjadi jawaban atas kerusakan tatanan masyarakat dan untuk membentuk tatanan baru. Islam merupakan totalitas dari segala aspek kehidupan sosial dan personal. Premis keagamaan tersebut dipandang sebagai petunjuk bahwa Islam menyediakan ajaran yang lengkap mengenai semua aspek kehidupan manusia termasuk konsep negara dan sistem pemerintahan.

Kedua pandangan tersebut ada pada posisi berseberangan sehingga kemudian juga berpengaruh pada bagaimana kelompok ataupun secara individual dari umat Islam mengekspresikan pandangannya. Ketika kelompok pertama memperjuangkan formalisasi syariat Islam, maka kelompok yang kedua menolak- nya. Kondisi seperti ini juga terjadi di Kota Tasikmalaya ketika ada sekelompok ajengan yang berupaya menegakan syariat Islam. Upaya penegakan syariat Islam yang dilakukan oleh para ajengan dengan menuntut Pemerintah Kota Tasikmalaya untuk membuat suatu peraturan daerah yang mengatur tentang pelaksanaan syariat Islam. Namun, apa yang para ajengan perjuangkan tersebut mendapatkan penentangan dari beberapa tokoh Islam yang lainnya. Selain menghadapi ketidakcocokan dari beberapa tokoh Islam para ajengan juga menghadapi penolakan dari beberapa ormas termasuk ormas Islam.

Setelah para ajengan sepekat untuk mengusulkan pelaksanaan syariat Islam kepada pemerintah kemudian para ajengan tersebut melakukan gerakan untuk penegakan syariat Islam di Kota Tasikmalaya dimulai dengan melakukan pertemuan dengan Walikota dan DPRD Kota Tasikmalaya. Ditengah perdebatan dan pergerakan yang berseberangan itu muncul kesepakatan bahwa untuk dapat diterima oleh semua masyarakat Kota Tasikmalaya penegakan syariat Islam tidak dilakukan secara ketat tetapi yang dilakukan adalah menata nilai-nilai kehidupan masyarakat sesuai dengan norma-norma sosial dan budaya Tasikmalaya yang religius. Dengan demikian, para ajengan menurunkan level tuntutan mereka, tidak lagi menuntut pelaksanaan syariat Islam secara menyeluruh diatur oleh peraturan daerah walaupun sebelumnya para ajengan tersebut telah menyerahkan 7 (tujuh) buah draft peraturan daerah mengenai syariat Islam, tetapi lebih kepada nilai-nilai subtantifnya saja yang kemudian dapat diformulasikan 
oleh DPRD ke dalam Peraturan Daerah No. 12 Tahun 2009 tentang Pembangunan Tata Nilai Kehidupan Kemasyarakatan yang Berlandaskan pada Ajaran Agama Islam dan Normanorma Sosial Masyarakat Kota Tasikmalaya.

Peraturan Daerah tersebut merupakan hasil dari kompromi yang melibatkan dua pihak yang berbeda pandangan baik di luar DPRD sampai pada isu penegakan syariat Islam ini melalui pembahasan di DPRD. Dikatakan demikian karena perdebatan mengenai masuknya isu penegakan syariat Islam ke dalam kebijakan pemerintrah daerah ini tidak hanya terjadi di tataran kelompok-kelompok masyarakat saja tetapi juga terjadi di dalam gedung DPRD. Ketika masuk ke ranah pembuatan kebijakan publik di dalam gedung DPRD, pada awalnya isu penegakan syariat Islam ini tidak dapat diterima oleh mayoritas anggota DPRD.

Konsep mengenai "tata nilai" kemudian dipandang sebagai jalan tengah yang dapat diterima oleh kedua belah pihak dibandingkan dengan konsep syariat Islam. Pihak-pihak baik dari unsur masyarakat maupun DPRD yang menolak penegakan syariat Islam melalui peraturan daerah seperti terlihat dari argumentasi mereka ketika dilaksanakan dengar pendapat pada tanggal 5, 6 dan 10 Agustus 2009 di Gedung DPRD yang menghadirkan semua unsur masyarakat dan organisasi kemasyarakatan di Kota Tasikmalaya. Sementara itu, tata nilai kehidupan kemasyarakatan yang berlandaskan kepada ajaran Agama Islam dan norma-norma sosial seperti yang dimaksud dalam Perda No. 12 Tahun 2009 dan Perda No. 7 Tahun 2014 yang telah disepakati adalah suatu tatanan kehidupan masyarakat yang menjunjung tinggi kemuliaan ajaran Islam yang bersumber pada al-Qur'an dan al-Sunnah sebagai tuntunan dan pedoman hidup bagi setiap muslim, baik dalam menjalankan kehidupan pribadi maupun kehidupan bermasyarakat, berbangsa dan bernegara.

Paparan di atas meneguhkan gagasan mengenai keberagamaan masyarakat di Kota Tasikmalaya. Sebagaimana dinyatakan oleh Mada Sukmajati (2011) bahwa karakteristik masyarakat Tasikmalaya adalah masyarakat yang relijius, atau kuat dalam mengekspresikan keberagamaannya. Secara sejarah, wilayah Tasikmalaya memiliki akar kesejarahan dalam gerakan Islam radikal. Kaum muslim di wilayah ini juga menampakkan karakteristik Islam dengan sentimen Islam yang kuat. Dalam bidang politik, semua partai politik Islam memperoleh kemenangan dan memperoleh kursi di legislatif dalam pemilihan umum 1999, 2004 dan 2009. Fenomena ini sangat khas, dan dengan alasan ini kemudian menjadikan daerah ini menjadi salah satu basis bagi semua partai Islam di Indonesia untuk mendapatkan dukungan.

Sebagaimana di beberapa wilayah di Indonesia berkait dengan munculnya tuntutan implementasi syariah di suatu wilayah, di Tasikmalaya fenomena ini juga sangat kuat terlihat (Sukmajati 2011). Fenomena sosial keagamaan yang lain yang menonjol di Tasikmalaya adalah berkembangnya gerakan Jamaah Ahmadiyah Indonesia. Gerakan sosial keagamaan ini berkembang dengan menggunakan strategi dakwah yang komprehensif sehingga jumlah komunitasnya meningkat secara signifikan dari waktu ke waktu. Gerak- 
an ini berhadapan dengan para da'i sehingga para da'i pun perlu melakukan strategi dakwah tertentu untuk mempertahankan tradisi keberagamaan mereka (Fatoni 2014).

Dengan demikian, kuatnya ekspresi keagamaan yang ditemukan di kalangan masyarakat Tasikmalaya dapat dipahami karena secara kesejarahan memang masyarakat ini memiliki akar gerakan keagamaan yang radikal. Proses sosial budaya yang berkembang selanjutnya memungkinkan kekuatan agama itu menjadi warna tersendiri (Tanthowi 2005). Fenomena tuntutan pemberlakuan syariah, dan kontestasi antara kekuatan tradisional dengan kekuatan Islam baru juga semakin menguatkan pernyataan akan kuatnya keberagamaan masyarakat Tasikmalaya, sehingga bagaimana pun konstalasi politik yang terjadi, pergeseran ekspresi dan orientasi masyarakat tetap dengan warna agama.

Meskipun dinamika sosial politik demikian tingginya, namun yang dapat dicatat dalam kajian ini adalah bahwa kuatnya sentimen agama pula yang dapat menyatukan berbagai perbedaan dalam dinamika sosial politik itu. Menjadi relevan untuk merujuk gagasan dari Muhammad Alfan Sidik (2017) dan David Samiyono Samiyono (2017) berkait dengan kekuatan kearifan lokal dalam menjaga harmoni masyarakat serta mencegah konflik. Dalam konteks masyarakat Kota Tasikmalaya kearifan lokal yang mendasari adalah kearifan lokal yang berbasis agama, yaitu agama Islam.

\section{Kesimpulan}

Persinggungan hukum Islam atau syariat Islam dengan sistem hukum yang berlaku di kalangan pesantren di Tasikmalaya diwakili dua kelompok besar pertama adalah pandangan yang menyatakan bahwa untuk mencari solusi dalam berbagai persoalan masyarakat dan dalam membentuk masyarakat yang Islami memerlukan keterlibatan negara, menjadikan Islam sebagai ideologi, yang manifestasinya adalah tuntutan pelaksanaan ajaran agama secara formal sebagai hukum positif. Kedua menyatakan bahwa untuk membentuk masyarakat Islami tidak perlu melibatkan negara. Pandangan ini lebih mendukung pelaksanaan etika atau moral agama dengan pendekatan kultural.

Dari kedua pandangan tersebut memengaruhi bagaimana kelompok ataupun individual dari umat Islam mengekspresikan pandangannya. Ketika kelompok pertama memperjuangkan formalisasi syariat Islam, maka kelompok yang kedua menolaknya. Kondisi seperti ini juga terjadi di Kota Tasikmalaya ketika ada sekelompok ajengan yang berupaya menegakan syariat Islam. Upaya penegakan syariat Islam yang dilakukan oleh para ajengan tersebut dilakukan dengan menuntut Pemerintah Kota Tasikmalaya untuk membuat suatu peraturan daerah yang mengatur tentang pelaksanaan syariat Islam.

Pada perkembanganya ada pergeseran cara pandang dan orientasi elit pesantren dalam penegakan syariat. Hal ini di buktikan dengan adanya kompromi antara kedua kelompok tersebut dalam pembuatan perda dengan dikeluarkannya Perda No. 7 tentang Tata Nilai. Perda tersebut merupakan solusi terhadap isu formalisasi Islam di Tasikmalaya. 
Konsep mengenai "tata nilai" kemudian dipandang sebagai jalan tengah yang dapat diterima oleh kedua belah pihak dibandingkan dengan konsep syariat Islam.[]

\section{Daftar Pustaka}

Bubalo, Anthony dan Greg Fealy Whit Meson. 2008. Zealous Democrats: Islamism and Democracy in Egypt, Indonesia and Turkey. New South Wales: Lowi Institute For International Policy.

Denzin, Norman dan Yvoanna S. Lincoln. 2009. Handbook of Qualitatif Reseserch. terj. Dariyanto. Yogyakarta: Pustaka Pelajar.

Effendy, Bahtiar. 2009. Islam dan Negara: Transformasi Gagasan dan Praktik Politik Islam di Indonesia. Jakarta: Paramadina.

Fatoni, Uwes. 2014. "Respon Da'i terhadap Gerakan Jemaat Ahmadiyah Indonesia (JAI) di Tenjowaringin Tasikmalaya." Jurnal Dakwah 15(1):49-65. Retrieved (http://ejournal.uin-suka.acid/dakwah/ jurnaldakwah/article/view/298).

Geertz, Clifford. 1983. Abangan, Santri, Priyayi dalam Masyarakat Jawa. terj. A. Mahasin, B. Rasuanto, P. Suparlan, dan H. W. Bachtiar. Jakarta: Pustaka Jaya.

Hefner, Robert W. 1995. ICMI dan Perjuangan Menuju Kelas Menengah Indonesia. Yogyakarta: Tiara Wacana.

Huntington, Samuel P. 2000. Benturan Antar Peradaban dan Masa Depan Politik Dunia. Yogyakarta: Qalam.

Ilahi, Mohammad Takdir. 2014. "Kiai: Figur Elite Pesantren." Ibda': Jurnal Kebudayaan Islam 12(2):137-48.
Jackson, Karl D. 1990. Kewibawaaan Tradisional, Islam, dan Pemberontakan: Kasus Darul Islam Jawa Barat. Jakarta: Pustaka Utama Grafiti.

Liddle, R. Willia. 1997. Islam, Politik, dan Modernisasi. Jakarta: Pustaka Sinar Harapan.

Muntoha. 2010. Otonomi Daerah dan Perkembangan "Peraturan Daerah Bernuansa Syari'ah". Yogyakarta: Safiria Insania Press.

Nasir, Haedar. 2007. Gerakan Islam Syariat: Reproduksi Salafiah Ideologis di Indonesia. Jakarta: Pusat Studi Agama dan Peradaban (PSAP).

Qodir, Zuly. 2012. Sosiologi Politik Islam: Kontestasi Islam Politik dan Demokrasi di Indonesia. Yogyakarta: Pustaka Pelajar.

Salim, Arskal. 2008. Challenging the Secular State: the Islamization of Law In Modern Indonesia. Honolulu: University Hawai'i Press.

Samiyono, David. 2017. "Membangun Harmoni Sosial: Kajian Sosiologi Agama Tentang Kearifan Lokal Sebagai Modal Dasar Harmoni Sosial." JSW: Jurnal Sosiologi Walisongo 1(2):195. Retrieved (http://journal.walisongo.ac.id/index.ph p/JSW/article/view/1994).

Sidik, Muhammad Alfan. 2017. "Kearifan Budaya Lokal sebagai Benteng Munculnya Konflik Agama." JSW: Jurnal Sosiologi Walisongo 1(2):161. Retrieved (http://journal.walisongo.ac.id/index.ph p/JSW/article/view/2035).

Smith, Jonathan A., Paul Flowers, dan Michael Larkin. 2009. Interpretative Phenomenological Analysis: Theory, Method and 
Research. Los Angeles, London, New Delhi, Singapore, Washington: Sage.

Suismanto. 2007. "Perda Syariat Islam dan Problematikanya (Kasus Tasikmalaya)." Jurnal Aplikasi Ilmu-ilmu Agama, 3(1):30-42.

Sukmajati, Mada. 2011. "How Islamic Parties Organize at the Local Level in PostSuharto Indonesia: An Empirical Study of Six Major Islamic Parties in the Tasikmalaya District, West Java Province." Disertasi. The Faculty of Economics and
Social Studies Universitats Bibliothek Heidelberg, Heidelberg.

Tanthowi, Pramono U. 2005. Kebangkitan Politik Kaum Santri: Islam dan Demokratisasi di Indonesia. Jakarta: Pusat Studi Agama dan Peradaban (PSAP).

Uhlin, Anders. 1995. Democracy and Diffusion Transnational Lesson-Drawing among Indonesia Pro-Democracy Actors. Sweden: Lund: Political Studies. 
This page is intentionally left blank 